\title{
The awareness of environmentally friendly products: The impact of green advertising and green brand image
}

\section{Doni Purnama Alamsyah ${ }^{a^{*}}$, Norfaridatul Akmaliah Othman ${ }^{b}$ and Hayder Alhadey Ahmed Mo- hammed $^{\mathrm{c}}$}

${ }^{a}$ Binus University, Indonesia

${ }^{b}$ Universiti Teknikal Malaysia Melaka, Malaysia

${ }^{c}$ Alzaeim Alazhari University, Sudan

\section{H R O N I C L E \\ A B S T R A C T}

Article history:

Received: October 16, 2019

Received in revised format:

January 302020

Accepted: February 10, 2020

Available online:

February 10, 2020

Keywords:

Green Advertising

Green Brand Image

Green Awareness

Green Purchase Intention

\begin{abstract}
Nowadays, customer awareness on environment friendly products is getting improved and there is an increase trend on green marketing strategy. The carried-out strategy has an objective of improving the customer care and purchasing intention on environment friendly products. Reviewing the issue of customer behavior, this study aims to review the correlation among green advertising, green brand image and customer green awareness on environment friendly products and their impacts to purchase intention. The study was conducted through a survey among 102 customers of Supermarket in Bandung City who have experience on friendly products. Data from the customers were obtained through a questionnaire, tabulated and processed by path analysis using SmartPLS. In order to emphasize research result, the research hypothesis test was conducted. Research finding explains that green advertising was assessed to be important by the customer and it can improve the customers' green awareness. On the other hand, it is stated that there was an impact of green awareness on improving customer purchasing intention on the environmentally friendly product. This study is useful for the supermarket in Indonesia particularly in understanding customer behavior to the environmentally friendly product. So, the implementation of the marketing strategy is more precise. Besides, this study can be an input for the Indonesian Government in implementing a regulation associated with the global warming issue through research on environmental friendly product.
\end{abstract}

\section{Introduction}

The environmentally friendly product is a product which is produced without chemical substances (Lian et al., 2016), for instance, organic product, as it is enriched by antioxidant needed by the body (Bonilla-Priego et al., 2014). The environmentally friendly product does not harm the consumer (Heslin \& Ochoa, 2008), hence the demand by the healthconscious consumer is high (Paço \& Raposo, 2010). Mohamad et al. (2010) suggested that consumer with health issue should consume environment friendly products such as organic vegetable. Consumer awareness of the benefits of the environmental friendly product has been improved due to consumers knowledge (Alamsyah \& Hariyanto, 2017). This has developed green consumerism where the consumer is more concern to save the world from global warming issue (Paço \& Raposo, 2010). The changing of consumer behavior on the environmental friendly product has influenced the company to pay more attention to the marketing strategy in order to improve green awareness among consumer (Yu-Shan Chen \& Chang, 2012). The company creates a marketing strategy to improve competitive advantage (Chen \& Chang, 2013). Competitive advantage will add value 
to the company in order to sustain competition in the market. The advantage of competitive advantage is surely for company performance (Rizwan et al., 2014) and it is assessed mainly from customer perspective (Tretyak \& Sloev, 2013). In addition, many companies in various countries have started to focus on marketing strategies of the environmental friendly product (Hartmann et al., 2005). There are many marketing strategies that can be implemented by the company in the relation to environmentally friendly product and green awareness of consumer; one of them is related to green advertising that takes attribute from the characteristic of the environmentally friendly product (Tiwari et al., 2011). Green advertising is used by some companies with the objective to improve consumer's knowledge about the product offered by the company and to gain consumer trust (Chang, 2012). Once consumer's knowledge is improved, it is hoped that it will affect consumer intention on the decision making (Rahmi et al., 2017). Today, green advertising strategy is not only conducted by the company in influencing consumer, but it is also being utilized by the government in public service advertisement for environmental issue (Fuerst \& Shimizu, 2016). Apart from green advertising, the green brand image also plays an important role to influence consumer behavior (Yu-shan Chen, 2010). The role of green brand image is very important for the company, where a company that has had a green brand image is one step ahead in the effort to get a competitive advantage (Yu-Shan Chen \& Chang, 2012). Green brand image means trust from consumer and creates a positive image for the company of environmentally friendly product (Hartmann et al., 2005). Consumer trust is hard to achieve as consumer trust does not achieve only by the quality of the environmentally friendly product, but on how the product demonstrate positively to the environment (Mourad et al., 2012). There are many brands in the supermarket which offer an environmentally friendly product; however, consumer trusts fewer products. Consumers evaluate the product based on the eco-label, packaging and product information (Ariffin et al., 2016). Consumer trust is increased through knowledge about the environmentally friendly product, hence it influences green brand value to the company (Jayaram et al., 2015). Green brand image is closely related to green awareness among consumer (Zdravkovic et al., 2010). Green brand image is used by the company to support company performance (Chen \& Chang, 2013). However, company performance can be measured through the improvement of consumer purchasing intention (Rizwan et al., 2014). Therefore, support on consumer behavior that leads to consumer purchasing intention is needed. The previous study has emphasized that consumer purchasing intention, especially for the environmentally friendly product, depends on green awareness (Wu \& Chen, 2014). In Indonesia, an environmentally friendly product like organic products is easy to get at the supermarket (Alamsyah \& Syarifuddin, 2018). However, the level of consumer trust is varied (Alamsyah et al., 2018), hence the supermarket must strengthen up the green marketing strategy through green advertising and green brand image (Ellison et al., 2016). The final objective of a green marketing strategy is to explore new market and to improve product value offered (Rahmi et al., 2017). The utilization of green advertising is very important in supporting the development of the environmentally friendly product; the consumer can easily be influenced by green advertising, for instance, the utilization of billboard aimed at assessing pleasurable, positive information, and trustworthy from product assessed by consumer (D'Souza $\&$ Taghian, 2005). At the same time, it will be able to influence green awareness among consumer, hence improves consumer purchasing intention for environmentally friendly product (Mourad et al., 2012). Besides, through advertisement, some attributes from the environmentally friendly product can be demonstrated (Tretyak \& Sloev, 2013), hence improve consumer care towards environmental friendly product and consumer purchase intention (Wu \& Chen, 2014). It has appeared that consumer interest in the environmentally friendly product in Indonesia is still low compared to the conventional product (Suki, 2013). This is because green awareness has not properly been developed. Therefore, this study looks into the phenomenon of Indonesian consumer behavior towards environmentally friendly product which focuses on green awareness among consumer on green advertising and green brand image. This study is essential due to the development from previous research (Zdravkovic et al., 2010) and the critical role of green awareness in the effort of facing the challenges of global warming issue (Wu \& Chen, 2014).

\section{Literature Review}

\subsection{Environmentally Friendly Products}

Environmental friendly product or commonly called as eco-friendly products are a product created or produced without chemical substances or other harmful material and does not impact negatively on a user and surrounding environment (Ellison et al., 2016; Haghjou et al., 2013; Tjarnemo \& Sodahl, 2015; Wu \& Chen, 2014). There are many kinds of environmentally friendly products, for instance, organic fertilizer for vegetable product (Shao \& Yang, 2014). The utilization of organic fertilizer does not harm the environment and increases the nutrient content in vegetables (Chan et al., 2012). The vegetable product that uses chemical substances in pesticides is very hard to get rid of it through wash or heat (Othman \& Rahman, 2014) and can cause diseases like cancer (Alamsyah \& Hariyanto, 2017). Although the environmentally friendly product does not harmful to the user, the consumer is still reluctant to purchase due to the low level of awareness. Environmentally friendly product in the supermarket, such as vegetables, rice, and fruits, are hardly been recognized by the consumer because of lack of green marketing strategy (Nsairi, 2012), while environmental issue should play an important role in the marketing strategy of the company (Rashid, 2009).

\subsection{Green Advertising}

Green advertising is conducted by the company through the effort of product campaign that is given the friendly elements to the environment (Chang, 2012). The campaign is not fully conducted to an environmentally friendly product; it is sometimes supported by environmental sustainability (Lin et al., 2015). The objective of green advertising is to educate the consumer about the product value delivered to fulfill the standard of environmental sustainability (Ariffin et al., 2016). It is known that 
there are three types of green advertising done by the company, which is product campaign relates to the biophysical environment, product campaign relates to green lifestyle, and company campaign relates to environmental responsibility (Tiwari et al., 2011). In this study, green advertising focuses on the environmentally friendly product where all elements of green advertising become marketer's judgment to be delivered to the consumer. The campaign is conducted through brochure, banner or billboard (D'Souza \& Taghian, 2005). The final result is expected that the campaign executed can give a positive view of environmentally friendly product to consumer and company (Jayaram et al., 2015). The use of appropriate green advertising can provide a good image for the company (Zdravkovic et al., 2010), so consumer trust is improved. The importance of green advertising as the company's marketing strategy is not only for introducing the product but also act as an educational platform from the government to disseminate information on an environmental issue like global warming (Ramirez, 2013). This is because environment issue has become everyone's responsibility (Mirvis et al., 2010). The previous study has confirmed that green advertising can improve consumer purchase intention (Haghjou et al., 2013) and create value for the company (Hasan et al., 2012). Green advertising is assessed through some criterions of consumer convenience level such as assesses organic product campaign (pleasant), consumer confidence level assesses campaign for organic product (convincing), consumer trust level assesses campaign for organic product (believable), consumer pleasure level assesses campaign for organic product (favorable) and improve positive view for organic product (good) (D’Souza \& Taghian, 2005).

\subsection{Green Brand Image}

One of the objectives of marketing strategy is to improve the value of a company through brand image (Chang, 2012; Gao et al., 2016), and in the context of the sustainable environment, marketing strategy aimed at collaborating the issue surrounding environmentally friendly product (Ellison et al., 2016; Gupta \& Kumar, 2013) and to gain a competitive advantage (Ellison et al., 2016). Green brand image is proven to give impact on consumer purchase intention (Chang, 2012) as it explains consumer judgment and perception on product image (Ramirez, 2013). Green brand image is formed based on consumers' mind through a series of perception (Mourad et al., 2012). In other words, green brand image is being interpreted by the consumer not only due to the company's social activities but through product offer (Kull \& Heath, 2016). Previous theories explained that green brand image was made through some judgments from the consumer. The judgement relates to different brand level with other brand (benchmarking) (Gupta \& Kumar, 2013), reputation level of company as the creator of environmental friendly product (reputation) (Alamsyah et al., 2017), company performance level assessed well in creating environmental friendly product (performance), company attention level of environmental friendly product (concern) and customer trust level to company (trustworthy) (Yu-shan Chen, 2010).

\subsection{Green Awareness}

Consumers' action toward the environment has become a major concern worldwide; it is marked with energy-saving movement to consumption pattern movement on the environmentally friendly product (Alamsyah et al., 2018). It is commonly called as green awareness, in which its impact on consumer behavior (Rahmi et al., 2017). Green awareness changes consumers' point of view from reducing conventional product consumption to recommending and selecting and choosing environmental friendly product (Suki, 2013). This was related closely to consumer knowledge on environment-friendly product characteristics (Tjarnemo \& Sodahl, 2015). Consumer purchase intention is determined by the green awareness of the environment-friendly product (Chang, 2012). Hence, the company should adjust marketing strategy to become pro-active and to learn further on the impact of green awareness on consumer behavior (Lin et al., 2015). Green awareness can develop well because of the implementation of green marketing in the company (Gupta \& Kumar, 2013). Green marketing is an integrated marketing concept of a company that uses environmental sustainability issue in order to fulfill consumer's needs (Polonsky, 2011). Furthermore, it has been known in the previous research that the level of consumer green awareness can be improved through marketing strategy of the company that based on an environment which captured in green advertising (Rahmi et al., 2017). Other strategies that also impact the green awareness of consumer is green brand image owned by the company (Mourad et al., 2012). Finally, green awareness as a source of consumer intention in choosing the product for the effort of marketing done by the company through green advertising and green brand image (Chan et al., 2012). In general, green awareness can be assessed from knowledge attitude of the environment which is the effort, label, slogan, symbol, and brand (Rizwan et al., 2014).

\subsection{Green Purchase Intention}

In environmental friendly product, green consumerism behavior relates closely to green purchase intention (Paço \& Raposo, 2010). Green purchase intention is expectation and consumer possibility to purchase an environmentally friendly product based on previous evaluation result (Yu-Shan Chen \& Chang, 2012). Green purchase intention is stated as consumer prediction towards the selection of environmentally friendly product (Othman \& Rahman, 2014). The intention is a basic consumer behavior relates to motivation in doing an action based on previous evaluation result that is conducted by consumer (Nsairi, 2012). Consumer purchase intention, if it is supported by adequate information, will develop well to positive behavior on purchasing (Wu \& Chen, 2014). In the context of the environmentally friendly product, the basic consumer motivation for the environmentally friendly product can be reviewed from the information of environmentally friendly product owned by consumer (Rashid, 2009). The information is obtained from green advertising and green brand image that has been conducted by the company. However, the development of the environmentally friendly product in Indonesia at present is still in the introduction stage (Mayrowani, 2012). This does not support consumer behavior on green purchase intention (Cynthia, 2013). 
Green purchase intention is often used to relate to consumer behavior for environmentally friendly product (Yu-Shan Chen \& Chang, 2012) because purchase intention becomes good predictor in purchasing behavior. Green purchase intention becomes a concept to consumer possibility and desire on product preference that has environmental friendly type hence affected purchase decision (Othman \& Rahman, 2014). The previous theory stated that purchase intention can be assessed from some indicators which are having the consideration to buying, priority to buy, feel to buy, recommend to buy and desire to buy more (Yu-Shan Chen \& Chang, 2012). If it is connected to the environmentally friendly product, so green purchase intention is a consideration, priority, feeling and recommendation to do environmentally friendly product purchasing.

\section{Methods and Hypothesis}

This study was conducted in Bandung City through experimental research on supermarket's consumer who purchased the environmentally friendly product. This is because the Supermarket had adopted some marketing strategies related to green marketing in Bandung City (Alamsyah \& Syarifuddin, 2018). A survey, utilizing a set of questionnaires, was conducted among supermarket's consumer because the environmentally friendly product can be easily purchased in Supermarket. The data was collected by random sampling to respondents who came to the supermarket, and a questionnaire was distributed directly to the respondents who took out the product from the shelves, to make sure all respondents are environment friendly product purchaser. A total of 120 respondents have participated in the survey which took place at the beginning of 2018.

\subsection{The Measurement of Research Variable}

This study focused on an environmentally friendly product with the objective to explore the variable of green advertising, green brand image, green awareness, and green purchase intention. Each variable was measured by some indicators. Green advertising was measured by pleasant, convincing, believable, favorable and good (D'Souza \& Taghian, 2005). Green brand image was measured by benchmark, reputation, performance, concern and trustworthy (Yu-shan Chen, 2010), while green awareness was measured by consumer environmental concern, awareness of the green product, awareness of price and awareness of brand image (Suki, 2013). Green purchase intention has used the measurement of willing to buy, priority to buy, feeling to buy, a recommendation to buy and willing to pay more (Yu-Shan Chen \& Chang, 2012). All variables were assessed by respondents with the value of questionnaire had been determined through multilevel scale, which was ' 1 ' for the value of very disagree and ' 6 ' for the value of very agree.

\subsection{Model Development}

Fig. 1 illustrates the research model for this study. Based on the theoretical review from the experts, it was discovered that there was a correlation between green advertising and green brand image with green awareness (Alamsyah et al., 2018; Rahim et al., 2012; Rahmi et al., 2017). Besides, it had been known that there was an impact of green awareness on the improvement of green purchase intention (Rizwan et al., 2014; Suki et al., 2016). This study focused on reviewing mediation from green awareness for green purchase intention. The research models were developed based on previous studies which explained that green purchase intention could also be assessed directly from green advertising (Chan et al., 2016) and green brand image (Rahmi et al., 2017). The hypothesis was developed based on the research model in Fig. 1.

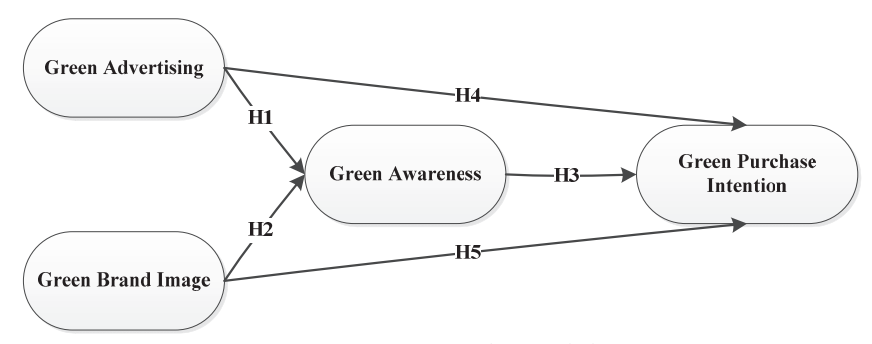

Fig. 1. Research Model

The following are the hypothesis that being developed for this study. A hypothesis test was conducted by using SEM analysis approach through data processing tools of SmartPLS.

Hypothesis $1(\mathrm{H} 1)$. Green advertising has an influence on green awareness.

Hypothesis 2 (H2). Green brand image has an influence on green awareness.

Hypothesis 3 (H3). Green awareness has an influence on green purchase intention.

Hypothesis 4 (H4). Green advertising has an influence on green purchase intention.

Hypothesis 5 (H5). Green brand image has an influence on green purchase intention.

\section{Results and Discussions}

This study continuous other previous surveys (Alamsyah et al., 2018), however, the basis of this research was developed by rating from green awareness on green purchase intention side. The study was conducted by experimental research to 120 consumers with 102 valid questionnaire data. There was $66.5 \%$ female; it demonstrated that female consumer dominated environmentally friendly product purchased in the supermarket. This is due to the household purchase among Indonesian were 
female responsibility. Majority of respondents hold a bachelor degree, which means that decision maker of an environmentally friendly product has good education level. It is in line with the previous study that the selection of environmentally friendly product is supported well from consumer knowledge (Mourad et al., 2012). This study aimed at exploring the impact of green advertising and green brand image on green awareness and green purchase intention. Detail finding was illustrated in Fig. 2 and Table 1.

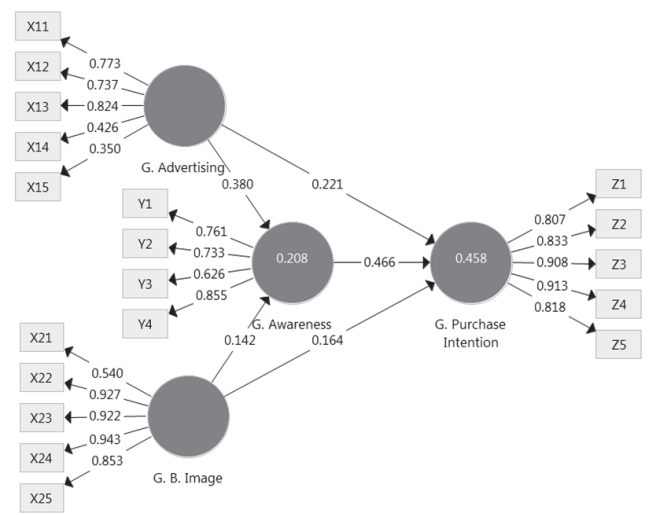

Fig. 2. Mediation Model of Green Awareness

Table 1

Hypothesis Test Result

\begin{tabular}{cccc}
\hline Hypothesis & Path Coefficients & t-value & Results \\
\hline H1 & 0.380 & 3.214 & 0.979 \\
H2 & 0.142 & 4.526 & Not supported \\
H3 & 0.466 & 2.169 & Supported \\
H4 & 0.221 & Supported & 2.089 \\
\hline
\end{tabular}

Based on the finding in Fig. 2, it is known that green advertising and green brand image had truly positive correlations with green awareness; it also correlates positively with green purchase intention. It can be interpreted that green purchase intention can be controlled well through green awareness or by supporting green advertising and green brand image. However, green advertising can control green awareness and green purchase intention better compared to the green brand image. Furthermore, the correlation value of green awareness directly to green purchase intention is higher than the correlation directly from green advertising to green purchase intention. If it is reviewed from mediation theory (Hayes, 2013), it can be explained that green awareness can actually be the mediation for the correlation of green advertising to green purchase intention. This study was based on a survey with the sample, so it emphasized by the hypothesis test result. Table 1 demonstrates that all of the correlation between research variable is stated to support $\mathrm{H} 1, \mathrm{H} 3, \mathrm{H} 4$, and $\mathrm{H} 5$ except the correlation of green brand image to green awareness $(\mathrm{H} 2)$. It emphasizes that green brand image which is owned by the company on an environmentally friendly product cannot control optimally to green awareness, especially for green purchase intention.

\subsection{The Improvement of Green Awareness of Customer through Green Advertising Implementation}

Nowadays, green advertising is conducted by the company with aims to improve product value through a campaign of an environmentally friendly product (D'Souza \& Taghian, 2005). This strategy is done not only to introduce product from the company but also to educate regarding the environmental issue as what has been done by the government. The impact of green advertising is very significant to consumer behavior who care for the environmentally friendly product (Rahmi et al., 2017). It is in line with recent research finding (Rahim et al., 2012) where it has been known that there is a correlation of improvement from green awareness of customer because of green advertising implementation (Fig. 2). Reviewing from the findings, it explains that marketing strategy through green advertising seems to be a strategy that can change consumer behavior for the environmentally friendly product. In the context of this study, the company, which is the supermarket, needs to put forward campaign on environmental because it is correlated to the environmentally friendly product. Green advertising is created by the company through the convenience of advertisement presentation that takes the environmentally friendly product as the main theme (Hartmann \& Apaolaza-Ibáñez, 2009), and to take into account on consumer matter (Chang, 2012). The messages of the advertisement should sufficient enough to act as trusted information about the environmentally friendly product, which can also be done through packaging (Rizwan et al., 2014). The finding demonstrated that green advertising can be assessed well and being accepted by the consumer. This is an important finding to marketer hence to put more effort into improving consumer care towards environmentally friendly products. This finding was supported by previous research by Rahim et al. (Rahmi et al., 2017). Rahmi et al. (2017) reviewed specifically on the importance of green advertising to promote and to improve consumer awareness towards the environmentally friendly product.

\subsection{The Correlation of Green Brand Image and Green Awareness of Customer on Environmentally Friendly Product}

Green brand image is an image that is created by the company that offered an environmentally friendly product (Gao et al., 2016). Green brand image is awarded to the company that notices the impact of the green product to the environment and to 
include the green process in its operation (Chen \& Chang, 2013). Green brand image is hard to secure in a short period; however, it is important as a proof that the company cares to the environment (Chan et al., 2012). Generally, brand image owned by the company can control the customer's point of view towards the company (Kull \& Heath, 2016). The brand image often affected consumer purchase intention (Wang \& Tsai, 2014), and consumer trust (Kim \& Ham, 2016). However, as illustrated in Fig. 2, the correlation value of the green brand image is not optima on consumer green awareness. It means that although the company has a green brand image, it is not always the case that consumer will aware of the product delivered. This is because supermarket consumer will normally select an environmentally friendly product based on the content information about the product, and not because of green brand image. This finding explains that in providing environmentally friendly product to the market, product originality, attribute, and content plays an important role compare to brand image. It concludes that, in order for an environmentally friendly product to be noticed by the consumer, not all strategies based on the environmental issue can be utilized. Basically, the objective of green brand image development is to get a good assessment from the consumer for the purpose of company benchmark, company reputation, company performance, company concern on environmental friendly product and consumer trustworthy towards company (Rahmi et al., 2017). Furthermore, the objective of green brand image development is to change consumers' view and to improve consumer intention on the environmentally friendly product offered by the company. However, the research finding demonstrated that green brand image does not affect consumers' view and intention well. This finding is not in line with previous research on the impact of the green brand image on green awareness (Mourad et al., 2012; Suki, 2013).

\subsection{The Support of Green Advertising on Green Awareness Behavior and Green Purchase Intention of Customer to Environmentally Friendly Product}

Green awareness is important to change consumer behavior towards environmental friendly product (Alamsyah et al., 2018). The company, through green marketing strategy, tries to improve green awareness for positive consumer behavior (Rahmi et al., 2017). This attitude is mainly from the consumer who concerns on the environment, environmentally friendly product compared to the conventional product, the consumer who understands that environmental friendly product has sacrificed for cost and consumer who cares for status and image from environmental friendly product (Suki, 2013). One benefit of green awareness on the environmental friendly product is the changing attitude of consumer intention (Alamsyah et al., 2018). This is in line with the finding of this study which was presented in Figure 2. Consumer intention is the first step of the consumer selection process on the environmental friendly product (Hartmann et al., 2005). Hence, the supermarket should be able to give more attention to green awareness in order to change consumer behavior towards the environmentally friendly product. Fig. 2 has also demonstrated that green advertising has a direct correlation to green advertising which contributes to a positive value on purchase intention. It means that consumer behavior can be influenced directly with green advertising. It has been known that green purchase intention can be controlled well directly from green awareness (Rahmi et al., 2017), and green advertising (D'Souza \& Taghian, 2005). Actually, green purchase intention can be recognized from the consumer's desire to doing the selection of environmentally friendly product (Rahmi et al., 2017). If it is given a chance, the consumer will keep consistent in selecting an environmentally friendly product. This attitude is not easy to appear from the consumer if it is not supported by sufficient knowledge of the environmentally friendly product (Othman \& Rahman, 2014). Consumer intention comes from consumer ability in recommending environmental friendly product to the others (Suki et al., 2016). In order to do this, adequate information is needed before disseminating the information to others. The environmentally friendly product is known to have a more expensive price than conventional product (Haghjou et al., 2013). However, if the customer has the intention for the environmentally friendly product, the price has not become a problem, hence environmentally friendly product becomes a premium product and not expensive product. Besides green advertising, there is a green brand image that becomes the assessment for green purchase intention. It is different from consumer care on the environmentally friendly product. Considering from the previous theory about mediation rules of Hayes (Hayes, 2013), it can be stated that green awareness can be as the mediator toward the correlation of consumer behavior between green advertising and green purchase intention. Bear in mind that the direct correlation value of green advertising on green purchase intention is lower than green awareness. The finding of this study has supported the previous study (Alamsyah et al., 2018) on consumer behavior towards the environmentally friendly product, especially on green awareness. However, this study has explored a new finding on the ability of green awareness as a mediator to improve green purchase intention. This finding can be served as useful information in supporting marketing strategy decision that is based on the environment.

\section{Conclusions}

The study was conducted to focus on environmentally friendly product, where it reviews the correlation of green advertising, green brand image to green awareness and the improvement of green purchase intention. It is known that green advertising and green brand image have maintained good correlation with green awareness and green purchase intention. Environmentally friendly product in Indonesia today is still at the introduction stage, for instance, organic product in the supermarket. Consumer intention in selecting an environmentally friendly product is still low compared to conventional production. It is caused by consumer care to an environmentally friendly product has not been optimum. In fact, green awareness among consumer to an environmentally friendly product is getting improved in the world recently, so the company started to include issues on the environment in the marketing strategy. The objective of green marketing strategy is to improve green awareness among consumer, hence leads to consumer purchase behavior. Based on research finding, it is known that green marketing strategy consisting of green advertising, has the ability to changing consumer behavior toward green awareness. Green advertising 
becomes important in green marketing strategy, compared to the green brand image. The environmentally friendly product is being offered in Indonesian supermarket, therefore, it needs the right information through green advertising in order to support consumer purchase intention on the environmentally friendly product. The company that offers environmentally friendly product needs to give attention to green marketing strategy. This has been proved by the model and finding of this study. Therefore, it is highly suggested for the company to put forwards strategy that impacts to green awareness in order to change consumer purchase behavior. This study gives a contribution to the company to focus more on the environmentally friendly product; information about green marketing strategy through green advertising needs to be noticed. Obviously, the green brand image does not impact optimally on consumer purchase behavior. However, this study does not provide detail information about consumer behavior on the environmentally friendly product, so it is suggested that further research should studies other consumer behavior variable, for instance, green perceived value and green brand attribute. In addition, because the environmentally friendly product has a few different segments, future study should concentrate on consumer demography. The finding of this study becomes important not only for the company that utilizing green marketing strategy but also for government in the implementation to face global warming issue through research on green consumer behavior.

\section{Acknowledgement}

The authors expand their gratitude to Binus University, Indonesia, and Universiti Teknikal Malaysia Melaka for the continuous support of this research.

\section{References}

Alamsyah, D. P., \& Hariyanto, O. I. B. (2017). Store image of organic product: Social responsibility and trust's mediator. Cyber and IT Service Management (CITSM), 2017 5th International Conference, 1-4.

Alamsyah, D. P., Suhartini, T., Rahayu, Y., Setyawati, I., \& Hariyanto, O. I. B. (2018). Green advertising, green brand image and green awareness for environmental products. IOP Conference Series: Materials Science and Engineering, 434.

Alamsyah, D. P., \& Syarifuddin, D. (2018). Store Image: Mediator of Social Responsibility and Customer Perceived Value to Customer Trust for Organic Products. IOP Conference Series: Materials Science and Engineering, 288.

Alamsyah, D. P., Trijumansyah, A., \& Hariyanto, O. I. B. (2017). Mediating of Store Image on Customer Trust for Organic Vegetables. Mimbar: Jurnal Sosial Dan Pembangunan, 33(1), 132-141.

Ariffin, S., Yusof, J. M., Putit, L., \& Shah, M. I. A. (2016). Factors Influencing Perceived Quality and Repurchase Intention Towards Green Products. Procedia Economics and Finance, 37(16), 391-396.

Bonilla-Priego, M. J., Font, X., \& Pacheco-Olivares, M. del R. (2014). Corporate sustainability reporting index and baseline data for the cruise industry. Tourism Management, 44, 149-160. https://doi.org/10.1016/j.tourman.2014.03.004

Chan, H. K., He, H., \& Wang, W. Y. C. (2012). Green marketing and its impact on supply chain management in industrial markets. Industrial Marketing Management, 41(4), 557-562. https://doi.org/10.1016/j.indmarman.2012.04.002

Chan, K., Ahmed, A., \& Tih, S. (2016). Green Advertising Appeal and Consumer Purchase Intention. 47, $157-168$.

Chang, C. T. (2012). Are guilt appeals a panacea in green advertising? The right formula of issue proximity and environmental consciousness. International Journal of Advertising, 31(4), 741-771. https://doi.org/10.2501/IJA-31-4-741-771

Chen, Y.-S., \& Chang, C.-H. (2013). Enhance environmental commitments and green intangible assets toward green competitive advantages : an analysis of structural equation modeling ( SEM ). Quality \& Quantity, 47, 529-543.

Chen, Yu-shan. (2010). The Drivers of Green Brand Equity: Green Brand Image, Green Satisfaction, and Green Trust. Journal of Business Ethics, 93(1), 307-319.

Chen, Yu-Shan, \& Chang, C. (2012). Enhance Green Purchase Intentions. The Roles of Green Perceived Value, Green Perceived Risk, and Green Trust. Management Decision, 50(3), 502-520.

Cynthia, B. (2013). Environmental Concern, Attitude Toward Green Corporate Practices, and Green Consumer Behavior in The United States and Canada. ASBBS EJournal, 9(1), 62-71.

D’Souza, C., \& Taghian, M. (2005). Green advertising effects on attitude and choice of advertising themes. Asia Pacific Journal of Marketing and Logistics, 17(3), 51-66.

Ellison, B., Duff, B. R. L., Wang, Z., \& White, T. B. (2016). Putting the organic label in context: Examining the interactions between the organic label, product type, and retail outlet. Food Quality and Preference, 49, 140-150.

Fuerst, F., \& Shimizu, C. (2016). Green luxury goods? The economics of eco-labels in the Japanese housing market. Journal of the Japanese and International Economies, 39, 108-122. https://doi.org/10.1016/j.jjie.2016.01.003

Gao, Y. L., Mattila, A. S., \& Lee, S. (2016). A meta-analysis of behavioral intentions for environment-friendly initiatives in hospitality research. International Journal of Hospitality Management, 54, 107-115.

Gupta, S., \& Kumar, V. (2013). Sustainability as corporate culture of a brand for superior performance. Journal of World Business, 48(3), 311-320. https://doi.org/10.1016/j.jwb.2012.07.015

Haghjou, M., Hayati, B., Pishbahar, E., Mohammadrezaei, R., \& Dashti, G. (2013). Factors affecting consumers' potential willingness to pay for organic food products in Iran: Case study of Tabriz. Journal of Agricultural Science and Technology, 15(2), 191-202.

Hartmann, P., \& Apaolaza-Ibáñez, V. (2009). Green advertising revisited, Conditioning virtual nature experiences. International Journal of Advertising, 28(4), 715-739. https://doi.org/10.2501/S0265048709200837

Hartmann, P., Iba, V. A., \& Sainz, F. J. F. (2005). Green branding effects on attitude: functional versus emotional positioning strategies. Marketing Intelligence \& Planning, 23(1), 9-29. https://doi.org/10.1108/02634500510577447

Hasan, J., Sumarwan, U., \& Suharjo, B. (2012). Factors Analysis in Desire to Buy Environmental Friendly Products Case Study for Air Condition Products. 5(8), 181-190. https://doi.org/10.5539/ibr.v5n8p181

Hayes, A. F. (2013). Introduction to Mediation, Moderation, and Conditional Process Analysis: A Regression-Based Approach. 
Guilford Press.

Heslin, P. A., \& Ochoa, J. D. (2008). Understanding and developing strategic corporate social responsibility. Organizational Dynamics, 37(2), 125-144. https://doi.org/10.1016/j.orgdyn.2008.02.002

Jayaram, D., Manrai, A. K., \& Manrai, L. A. (2015). Effective use of marketing technology in Eastern Europe: Web analytics, social media, customer analytics, digital campaigns and mobile applications. Journal of Economics, Finance and Administrative Science, 20(39), 118-132. https://doi.org/10.1016/j.jefas.2015.07.001

Kim, E., \& Ham, S. (2016). Restaurants' disclosure of nutritional information as a corporate social responsibility initiative: Customers' attitudinal and behavioral responses. International Journal of Hospitality Management, 55, 96-106.

Kull, A. J., \& Heath, T. B. (2016). You decide, we donate: Strengthening consumer-brand relationships through digitally co-created social responsibility. International Journal of Research in Marketing, 33(1), 78-92.

Lian, S. B., Safari, M., \& Mansori, S. (2016). The effects of marketing stimuli factors on consumers' perceived value and purchase of organic food in Malaysia. Jurnal Pengurusan, 47, 119-130.

Lin, C. P., Tsai, Y. H., Chiu, C. K., \& Liu, C. P. (2015). Forecasting the purchase intention of IT product: Key roles of trust and environmental consciousness for IT firms. Technological Forecasting and Social Change, 99, 148-155.

Mayrowani, H. (2012). Pengembangan Pertanian Organik di Indonesia. Forum Penelitian Agro Ekonomi, 30(2), 91-108.

Mirvis, P., Googins, B., \& Kinnicutt, S. (2010). Vision, mission, values. Guideposts to sustainability. Organizational Dynamics, 39(4), 316-324. https://doi.org/10.1016/j.orgdyn.2010.07.006

Mohamad, M., Meriam, S., Harniza, E., Abdul, M., \& Rizaimy, M. (2010). Consumer's Perception and Purchase Intentions Towards Organic Food Products : Exploring Attitude Among Academician. Canadian Social Science, 6(6), 119-129.

Mourad, M., Serag, Y., Ahmed, E., \& Ahmed, Y. S. E. (2012). Perception of green brand in an emerging innovative market. European Journal of Innovation Management, 15(4), 514-537. https://doi.org/10.1108/14601061211272402

Nsairi, Z. B. (2012). Managing browsing experience in retail stores through perceived value: Implications for retailers. International Journal of Retail and Distribution Management, 40(9), 676-698.

Othman, C., \& Rahman, M. S. (2014). Investigation of the relationship of brand personality, subjective norm and perceived control on consumers' purchase intention of organic fast food. Modern Applied Science, 8(3), 92-106.

Paço, A. M. F., \& Raposo, M. L. B. (2010). Green Consumer Market Segmentation: Empirical Findings From Portugal. International Journal of Consumer Studies, 34(1996), 429-436. https://doi.org/10.1111/j.1470-6431.2010.00869.x

Polonsky, M. J. (2011). Transformative green marketing: Impediments and opportunities. Journal of Business Research, 64(12), 1311-1319. https://doi.org/10.1016/j.jbusres.2011.01.016

Rahim, M. H. A., Zukni, R. Z. J. A., Ahmad, F., \& Lyndon, N. (2012). Green advertising and environmentally responsible consumer behavior: The level of awareness and perception of Malaysian youth. Asian Social Science, 8(5), 46-54.

Rahmi, D. Y., Rozalia, Y., Chan, D. N., Anira, Q., \& Lita, R. P. (2017). Green Brand Image Relation Model, Green Awareness, Green Advertisement, and Ecological Knowledge as Competitive Advantage in Improving Green Purchase Intention and Green Purchase Behavior on Creative Industry Products. Journal of Economics, Business \& Accountancy Ventura, 20(2).

Ramirez, E. (2013). Consumer-defined sustainably-oriented firms and factors influencing adoption. Journal of Business Research, 66(11), 2202-2209. https://doi.org/10.1016/j.jbusres.2012.01.012

Rashid, N. R. N. A. (2009). Awareness of Eco-label in Malaysia's Green Marketing Initiative. International Journal of Business and Management, 4(8), P132. https://doi.org/10.5539/ijbm.v4n8P132

Rizwan, M., Mahmood, U., Siddiqui, H., \& Tahir, A. (2014). An Empirical Study about Green Purchase Intentions. Journal of Sociological Research ISSN Journal of Sociological Research, 5(1), 290-305. https://doi.org/10.5296/

Shao, S., \& Yang, L. (2014). Natural resource dependence, human capital accumulation, and economic growth: A combined explanation for the resource curse and the resource blessing. Energy Policy, 74(C), 632-642.

Suki, N. M. (2013). Green awareness effects on consumers' purchasing decision: Some insights from Malaysia. International Journal of Asia-Pacific Studies, 9(2), 49-63.

Suki, N. M., Suki, N. M., \& Azman, N. S. (2016). Impacts of Corporate Social Responsibility on the Links Between Green Marketing Awareness and Consumer Purchase Intentions. Procedia Economics and Finance, 37(16), 262-268.

Tiwari, S., Tripathi, D. M., Srivastava, U., \& Yadav, P. K. (2011). Green Marketing - Emerging Dimensions. Journal of Business Excellence, 2(1), 18-23.

Tjarnemo, H., \& Sodahl, L. (2015). Swedish food retailers promoting climate smarter food choices-Trapped between visions and reality? Journal of Retailing and Consumer Services, 24(C), 130-139.

Tretyak, O. A., \& Sloev, I. (2013). Customer flow: Evaluating the long-term impact of marketing on value creation. Journal of Business and Industrial Marketing, 28(3), 221-228. https://doi.org/10.1108/08858621311302877

Wang, Y., \& Tsai, C. (2014). The Relationship Between Brand Image and Purchase Intention: Evidence From Award Winning Mutual Funds. International Journal of Business \& Finance Research, 8(2), 27-40.

Wu, S.-I., \& Chen, Y.-J. (2014). The Impact of Green Marketing and Perceived Innovation on Purchase Intention for Green Products. International Journal of Marketing Studies, 6(5), 81-101. https://doi.org/10.5539/ijms.v6n5p81

Zdravkovic, S., Magnusson, P., \& Stanley, S. M. (2010). Dimensions of fit between a brand and a social cause and their influence on attitudes. International Journal of Research in Marketing, 27(2), 151-160.

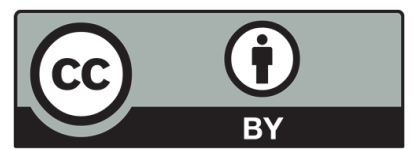

(C) 2020 by the authors; licensee Growing Science, Canada. This is an open access article distributed under the terms and conditions of the Creative Commons Attribution (CC-BY) license (http://creativecommons.org/licenses/by/4.0/). 